\title{
A Scoping Review of Practitioner Research on Sensitive Topics
}

\author{
Håvard Haugstvedt \\ Faculty of Social Sciences \\ University of Stavanger \\ Email: havard.haugstvedt@uis.no
}

\begin{abstract}
Practitioner research, which involves professionals such as social workers, educators, and nurses, is an approach that may help establish contact with hard-to-reach targets while also exposing the researcher to potentially sensitive and ethically challenging situations and dilemmas. Through a scoping review of the scholarly literature, this paper explores evidence of the effects that research on sensitive topics may have on the researcher and how the researcher can prepare for this. Twenty-four peer-reviewed articles were analysed using thematic analysis, which provided the following four themes: researcher competency, researcher vulnerability, researcher role, and participant vulnerability. In addition, peer support, formal support measures, and research and time management were found to potentially counteract the adverse effects of conducting qualitative research on sensitive topics. The findings of this scoping review strongly suggest that practitioner researchers investigating sensitive issues should partner with professional research institutions from the beginning of the research process to end. In addition, strengthening the research methodology used during the bachelor's degree educations of professionals such as social workers might help to develop more resilient practitioner researchers. This must, however, be weighed against other necessary courses.
\end{abstract}

Keywords: practitioner research, qualitative research, sensitive topics, social work research

\section{Introduction}

Several approaches within qualitative research are carried out through interactions between the researcher and the subjects of the research. This enables the researcher to approach close the topic closely. Being close to the human experience that the study 
addresses is a requirement of qualitative data collection (Kirkevold \& Bergland, 2007, p. 67). However, this closeness may also expose the researcher to situations that may cause emotional reactions (Davis, 2000; Seidman, 2006, p. 68). These reactions may be explained by the subjectivity of qualitative research, in which the researcher is a part of the experience and interacts with and interprets what's 'going on' (Austin \& Sutton, 2014; Patton, 1999).

Like qualitative research in general, practitioner research encompasses many different traditions, movements, and methodologies. However, it is distinguished from other more traditional forms of research because it is usually conducted by practitioners as a part of their daily work (Ellis \& Loughland, 2016). Practitioner research is often described as being carried out by a professional with substantial insight into the community, as well as the community members who are the subjects of the research (Drake \& Heath, 2010). Often, the researcher's position is simplified as either that of an insider or outsider. However, this distinction has been contested by some scholars (Brown, 1996; Drake \& Heath, 2010), who have emphasized that there is a higher level of complexity and nuance involved, such as an insider-outsider position. This might be former a social worker or police officer, now working as a researcher. Vaswani (2018) argues that practitioner researchers are in a position to provide access to individuals and groups that may be hard for others to reach because practitioner researchers interact with them or their organization on a daily basis. Connecting closely with one's research participants is more difficult when researching within one's own organization or professional social context (Tietze, 2012), especially in regard to vulnerable service users or clients.

This article understands practitioner research as research carried out by active or former practitioners who are close to or part of organizations that provide services to client or patient groups (Drake \& Heath, 2010; Meghan, 2019; Shaw \& Lunt, 2018). Additionally, the point of departure for this work is the position of being a practitioner researcher - a former social worker engaged in exploring a specific practice field within the social work profession.

According to Parsons (1969, p. 331), professionals perform certain specialized functions for others in society based on a high level of specialized competence, with attendant fiduciary responsibility. Clearly, researching the same subject that they provide services 
for may cause tension among the professionals themselves. This alternation between roles may also cause uncertainty regarding who the professionals are at different times, potentially affecting others' expectations of them. In professional life, work role expectations include behaviour, appearance, and emotional display (Hochschild, 2003). Additionally, being part of a research project in one's own organization may also raise some ethical concerns, such as the power dynamics between the researcher and potential participants (Riese, 2019). However, this may also constitute a beneficial flipside-of-the-coin situation; if the researcher is well known to participants, those participants might open up more and experience the process as safer. Overall, this paints a picture of practitioner research as complex, with a myriad of roles and expectations to be managed and potential ethical pitfalls to consider at the design stage of the research project.

A lack of confidence in research knowledge and skills has been found among practising social workers, negatively influencing them and deterring them from undertaking practitioner research (Harvey et al., 2013). There may be additional concerns when researching sensitive topics, which are understood as those matters that people prefer not to discuss publicly due to the perceived risk associated with self-disclosure (Sydor, 2013), such as researching victims of domestic abuse or engaging with violent offenders. Although topics of a sensitive nature vary in their particulars, they may cause the researcher to experience unpleasant emotions. Because some individuals may also be hard to reach (Flanagan \& Hancock, 2010, p. 1), cooperating with communities, professionals, and other organisations working with them (Bonevski et al., 2014, p. 24) may create access to these individuals and groups.

The comprehensive public welfare policies found in the Nordic countries include social security, healthcare, and education and thus involve professionals such as social workers, nurses, psychologists, and educators (Normann et al., 2014, p. 21). Because these services are free to the majority of the population (Hoydal, 2018), the practitioners employed by them are in a position to establish closer relationships with hard-to-reach groups. The Nordic context is therefore of particular interest because its vast welfare system could suggest the use of practitioners to carry out research on sensitive topics or hard-to-reach participant groups. 
While both practitioner research and researching sensitive topics are not new research subjects, this article aims to identify and explore patterns in research conducted in the fields of social work, children and youth work, nursing, and clinical psychology, in which sensitive and unpleasant topics regularly surface as a part of practice. These professional contexts are what make practitioner research interesting. While sensitive topics themselves may be challenging to explore, as shown above, the complexity of the various roles and expectations within practitioner research makes this approach of particular relevance in exploring sensitive and ethically challenging topics.

This review of peer-reviewed literature examines the evidence regarding the stated challenges involved in conducting research on sensitive topics, pitfalls, dilemmas, and strategies in practitioner research. In this way, it explores the findings of past research studies to discover researchers' negative experiences, as well as considering how one might prepare for or prevent these experiences. The findings of this scoping review may help strengthen practitioners' motivation to engage in practitioner research on hard-toreach participants by helping prepare them for the task, execute the research, and protect both themselves and their research participants during the process

Research question: How does conducting qualitative research on sensitive and ethically challenging topics affect the researcher and participant, and how can the practitioner researcher prepare for this?

\section{Methodology}

The research question will be answered through a scoping review of the literature on practitioner research on sensitive or ethically challenging topics. While scoping reviews are related to systematic reviews, some differences set them apart. A scoping review aims to map the body of literature on a specific topic, while a systematic review aims to present the best available research on a specific question and evaluate the strength of the included studies (Pham et al., 2014, p. 372). However, both must present a rigorous, transparent methodology that includes a search strategy, inclusion criteria, and selection process (Munn et al., 2018; Pham et al., 2014). Because scoping reviews employ more expansive inclusion criteria, they typically include a larger amount of research than 
systematic reviews (Pham et al., 2014). Thus, a scoping review can serve as a precursor to a more specific targeted systematic review (Munn et al., 2018, p. 4).

\section{Inclusion Criteria}

Because this scoping review aims to uncover the scholarly literature on practitioner research involving sensitive and ethically challenging topics, the search process began by applying these terms as search words. The criteria guiding the selection process for articles were as follows: the studies must have been conducted by practitioner researchers on a sensitive or ethically challenging issue; they must have departed from or within organizations providing services; and they must have described experiences, dilemmas, challenges, or recommendations as part of their findings and discussion. The terminology used to describe research strategy differed, and variations such as 'action research', 'insider research', and others did occur. Review articles that provided insight into the above were deemed valuable and worth including in this scoping review. To secure the most recent findings, studies published prior to the year 2000 were excluded. Research carried out outside of or disconnected from the practice field or its organizations and services was excluded from this review.

\section{Search Strategy}

Data collection was conducted through a systematic search of the following databases: Academic Search Premier, Cinahl with Full Text, ERIC, MEDLINE, Soclndex with Full Text, and Scopus. The first search strategy used a combination of the following terms in all databases: 'sensitive topic or sensitive information or sensitive research or sensitive question*' AND 'practitioner research or practitioner researcher'. The search was limited peer-reviewed articles. See Table 1 for details. 
Table 1

\begin{tabular}{|l|l|l|}
\hline \multicolumn{4}{|l|}{ Table 1 - Search strategy 1 } \\
\hline Search step & Action & Result \\
\hline S1 & $\begin{array}{l}\text { Sensitive topic OR sensitive information OR sensitive } \\
\text { research OR sensitive question }\end{array}$ & 14,014 \\
\hline S2 & Practitioner research OR practitioner researcher & 37,588 \\
\hline S3 & S1 AND S2 & 48 \\
\hline S4 & Limitation: Peer-reviewed, published after 2000 & 35 \\
\hline S5 & Manual screening of titles, abstracts and full texts & 2 \\
\hline
\end{tabular}

This method identified only 35 articles, two of which were identified as relevant to the aim of this scoping review. A second strategy was used, producing similar results. See Table 2 for details.

\section{Table 2}

\begin{tabular}{|l|l|l|}
\hline Table 2 - Search strategy 2 \\
\hline Search step & Action & Result \\
\hline S1 & $\begin{array}{l}\text { Sensitive topic OR sensitive information OR sensitive } \\
\text { research OR sensitive question }\end{array}$ & 16,510 \\
\hline S2 & Interview OR research OR study & 12,616 \\
\hline S3 & $\begin{array}{l}\text { Professional OR practitioner OR nurs* OR police OR } \\
\text { social work OR psycholog* }\end{array}$ & $6,003,347$ \\
\hline S4 & S1 AND S2 AND S3 & 9 \\
\hline S5 & Limitation: Peer-reviewed, published after 2000 & 8 \\
\hline S6 & Manual screening of titles, abstracts, and full texts & 2 \\
\hline
\end{tabular}

Because the search strategies mentioned above proved ineffective, a much widerreaching search using fewer criteria was conducted. See Table 3 for details.

\section{Table 3}

\begin{tabular}{|l|l|l|}
\hline Table 3 - Search strategy 3 \\
\hline Search step & Action & Result \\
\hline S1 & Sensitive or delicate or touchy & $1,246,378$ \\
\hline S2 & Practitioner research or action research & 81,017 \\
\hline S3 & S1 AND S2 & 1040 \\
\hline S4 & Limitation: Peer-reviewed, published after 2000 & 812 \\
\hline S5 & Manual screening of titles, abstracts and full texts & 17 \\
\hline
\end{tabular}


This search retrieved 17 new studies, as well as the four identified in the earlier search strategies. Three additional studies matching the criteria were found through other sources, bringing the total number of included articles to 24 . The search process is shown in Figure 1.

\section{Figure 1}

\begin{tabular}{|c|c|c|}
\hline \multirow[t]{3}{*}{ Identification } & $\begin{array}{l}\text { Records identified in search } \\
\text { strategy } 1(n=17)\end{array}$ & \multirow[t]{3}{*}{$\begin{array}{l}\text { Additional records identified } \\
\text { through other sources }(n=12)\end{array}$} \\
\hline & $\begin{array}{l}\text { Records identified in search } \\
\text { strategy } 2(n=8)\end{array}$ & \\
\hline & $\begin{array}{l}\text { Records identified in search } \\
\text { strategy } 3(n=812)\end{array}$ & \\
\hline \multicolumn{3}{|c|}{ Records after duplicates removed ( $n=749$ ) } \\
\hline Screening & Records screened ( $n=749$ ) & Records excluded ( $n=702)$ \\
\hline Eligibility & $\begin{array}{l}\text { Full-text articles assessed for } \\
\text { eligibility }(n=47)\end{array}$ & Full-text articles excluded $(n=23)$ \\
\hline Included & Studies included $(n=24)$ & \\
\hline
\end{tabular}

Figure 1 - Flow diagram, adapted from PRISMA (Preferred Reporting Items for Systematic Reviews and Meta-Analyses) flow diagram by Moher et al. (2009)

\section{Results}

In total, 24 studies were included in this scoping review. Table 4 shows all included studies organized by publication year. 
Table 4

\begin{tabular}{|c|c|c|c|c|c|c|c|c|}
\hline Title & $\begin{array}{l}\text { 'Doing Research in } \\
\text { Peoples' Homes: } \\
\text { Fieldwork, Ethics } \\
\text { and Safety - On } \\
\text { the Practical } \\
\text { Challenges of } \\
\text { Researching and } \\
\text { Representing Life } \\
\text { on the Marging' }\end{array}$ & $\begin{array}{l}\text { 'Understanding } \\
\text { Ethics in School- } \\
\text { Based Research' }\end{array}$ & $\begin{array}{l}\text { 'Learning from } \\
\text { Failure: Are } \\
\text { Practitioner } \\
\text { Researchers the } \\
\text { Answer } \\
\text { when Conducting } \\
\text { Research on } \\
\text { Sensitive Topics } \\
\text { with Vulnerable } \\
\text { Children and } \\
\text { Young People?' }\end{array}$ & $\begin{array}{l}\text { 'Reflexive } \\
\text { Research with } \\
\text { Mothers and } \\
\text { Children Victims } \\
\text { of Domestic } \\
\text { Violence' }\end{array}$ & $\begin{array}{l}\text { 'Surviving } \\
\text { Research on } \\
\text { Sensitive Topics } \\
\text { with Young } \\
\text { Offenders' }\end{array}$ & $\begin{array}{l}\text { 'A Qualitative } \\
\text { Exploration of } \\
\text { Researcher Trauma } \\
\text { and Researchers' } \\
\text { Responses to } \\
\text { Investigating } \\
\text { Sexual Violence' }\end{array}$ & $\begin{array}{l}\text { 'Researcher or } \\
\text { Nurse? Difficulties } \\
\text { of Undertaking } \\
\text { Semi-Structured } \\
\text { Interviews on } \\
\text { Sensitive Topics' }\end{array}$ & $\begin{array}{l}\text { 'Conducting } \\
\text { Research into } \\
\text { Hidden } \\
\text { or Hard-to-Reach } \\
\text { Populations' }\end{array}$ \\
\hline Authors & Bashir, N. & $\begin{array}{l}\text { Bryan, } \mathrm{H}, \text { \& } \\
\text { Burstow, B. }\end{array}$ & Vaswani, N. & $\begin{array}{l}\text { Gabriel, L., James, } \\
\text { H., Cronin-Davids, } \\
\text { J., Tizzo, Z., } \\
\text { Beetham, T, } \\
\text { Hullock, A., \& } \\
\text { Raynar, A. }\end{array}$ & Hassan, N. & $\begin{array}{l}\text { Coles, J., Astbury, } \\
\text { J., Dartnall, E., \& } \\
\text { Limjerwala, S. }\end{array}$ & Ashton, S. & Sydor, $A$. \\
\hline Publication year & 2018 & 2018 & 2018 & 2017 & 2016 & 2014 & 2014 & 2013 \\
\hline Journal & $\begin{array}{l}\text { Qualitative } \\
\text { Research }\end{array}$ & $\begin{array}{l}\text { Development in } \\
\text { Education }\end{array}$ & $\begin{array}{l}\text { Intermational } \\
\text { Journal of Social } \\
\text { Research } \\
\text { Methodology }\end{array}$ & $\begin{array}{l}\text { Counselling and } \\
\text { Psychotherapy } \\
\text { Research }\end{array}$ & $\begin{array}{l}\text { Scottish Joumal of } \\
\text { Residential Child } \\
\text { Care }\end{array}$ & $\begin{array}{l}\text { Violence against } \\
\text { Women }\end{array}$ & Nurze Researcher & Nurse Researcher \\
\hline Aim/topic & $\begin{array}{l}\text { Explore the ethical } \\
\text { dilemmas and } \\
\text { health and safety } \\
\text { challenges of } \\
\text { conducting in- } \\
\text { depth qualitative } \\
\text { interviews with } \\
\text { 'vulnerable' } \\
\text { research } \\
\text { participants in their } \\
\text { oun homes. } \\
\end{array}$ & $\begin{array}{l}\text { Explore } \\
\text { the ways in which } \\
\text { research-active } \\
\text { schools are aware } \\
\text { of and using ethical } \\
\text { guidance in their } \\
\text { research practices. }\end{array}$ & $\begin{array}{l}\text { Review and report } \\
\text { the literature on } \\
\text { practical, ethical, } \\
\text { and methodological } \\
\text { considerations } \\
\text { when } \\
\text { conducting } \\
\text { research on } \\
\text { gensitive topics or } \\
\text { with vulnerable } \\
\text { children }\end{array}$ & $\begin{array}{l}\text { Explore a reflexive } \\
\text { and participatory } \\
\text { research approach } \\
\text { with a vulnerable } \\
\text { population. }\end{array}$ & $\begin{array}{l}\text { Share practical } \\
\text { challenges raised } \\
\text { during fieldwork } \\
\text { and explain how } \\
\text { these were handled } \\
\text { in appropriate } \\
\text { ways. }\end{array}$ & $\begin{array}{l}\text { Explore the trauma } \\
\text { experiences of } \\
\text { gexual violence } \\
\text { researchers from } \\
\text { different countries. }\end{array}$ & $\begin{array}{l}\text { Reflect on the } \\
\text { author's personal } \\
\text { and professional } \\
\text { experiences when } \\
\text { undertaking } \\
\text { research on } \\
\text { gensitive topics. }\end{array}$ & $\begin{array}{l}\text { Explore the } \\
\text { problems involved } \\
\text { in conducting } \\
\text { research with } \\
\text { populations that } \\
\text { are hidden or hard } \\
\text { to reach and } \\
\text { suggest strategies } \\
\text { to recruit } \\
\text { participants. }\end{array}$ \\
\hline
\end{tabular}

\begin{tabular}{|c|c|c|c|c|c|c|c|c|}
\hline Title & $\begin{array}{l}\text { 'Ethical Review } \\
\text { and Reflexivity in } \\
\text { Research of } \\
\text { Children's } \\
\text { Sexuality' }\end{array}$ & $\begin{array}{l}\text { 'Ethical Dilemmas } \\
\text { for Clinical } \\
\text { Psychologists in } \\
\text { Conducting } \\
\text { Qualitative } \\
\text { Research' }\end{array}$ & $\begin{array}{l}\text { 'Interviewing } \\
\text { People about } \\
\text { Potentially } \\
\text { Sengitive Topics' }\end{array}$ & $\begin{array}{l}\text { 'Practice Research: } \\
\text { What It is and Its } \\
\text { Place in the Social } \\
\text { Work Profession' }\end{array}$ & $\begin{array}{l}\text { 'An Embodied } \\
\text { Response: Ethics } \\
\text { and the Nurse } \\
\text { Researcher' }\end{array}$ & $\begin{array}{l}\text { 'Practitioner } \\
\text { Research in Social } \\
\text { Work: A } \\
\text { Knowledge } \\
\text { Review' }\end{array}$ & $\begin{array}{l}\text { 'Practitioner } \\
\text { Research, Ethics } \\
\text { and } \\
\text { Research } \\
\text { Governance' }\end{array}$ & $\begin{array}{l}\text { 'Risk to } \\
\text { Researchers in } \\
\text { Qualitative } \\
\text { Research on } \\
\text { Sensitive Topics: } \\
\text { Issues and } \\
\text { Strategies' }\end{array}$ \\
\hline Authors & Flanagan, $\mathrm{P}$. & $\begin{array}{l}\text { Thompson , A., R. } \\
\text { \& Russo, } \mathrm{K} \text {. }\end{array}$ & $\begin{array}{l}\text { Elmir, R, } \\
\text { Schmied, V., } \\
\text { Jackson, D., \& } \\
\text { Wilkes, L. }\end{array}$ & Pain, $\mathrm{H}$. & Clancy, A. & $\begin{array}{l}\text { Mitchell, F, Lunt, } \\
\text { N., \& Shaw, I. }\end{array}$ & $\begin{array}{l}\text { Lunt, N., \& } \\
\text { Fouche, C. }\end{array}$ & $\begin{array}{l}\text { Dickson-Swift, V, } \\
\text { James, E. L., } \\
\text { Kippen, S., \& } \\
\text { Liamputtong, p. }\end{array}$ \\
\hline Publication year & 2012 & 2012 & 2011 & 2011 & 2011 & 2010 & 2010 & 2008 \\
\hline Journal & Sex Education & $\begin{array}{l}\text { Qualitative } \\
\text { Research in } \\
\text { Psychology }\end{array}$ & Nurse Researcher & $\begin{array}{l}\text { European Joumal } \\
\text { of Social Work }\end{array}$ & Nursing Ethics & Evidence \& Policy & $\begin{array}{l}\text { Ethics and Social } \\
\text { Welfare }\end{array}$ & $\begin{array}{l}\text { Qualitative Heaith } \\
\text { Research }\end{array}$ \\
\hline Aim/topic & $\begin{array}{l}\text { Review research on } \\
\text { gensitive childhood } \\
\text { igsues. }\end{array}$ & $\begin{array}{l}\text { Explore the range } \\
\text { of ethical issues in } \\
\text { relation to } \\
\text { psychologists } \\
\text { conducting } \\
\text { qualitative } \\
\text { research. }\end{array}$ & $\begin{array}{l}\text { Explore the } \\
\text { challenges of } \\
\text { interviewing } \\
\text { people about } \\
\text { gensitive topics. }\end{array}$ & $\begin{array}{l}\text { Explore the main } \\
\text { topics raised in the } \\
\text { literature review } \\
\text { concerning practice } \\
\text { research in social } \\
\text { work. }\end{array}$ & $\begin{array}{l}\text { Reflect on } \\
\text { situational ethics in } \\
\text { qualitative } \\
\text { research. }\end{array}$ & $\begin{array}{l}\text { Map practitioner } \\
\text { research in social } \\
\text { work. }\end{array}$ & $\begin{array}{l}\text { Explore how } \\
\text { practitioner } \\
\text { research should } \\
\text { respond to calls for } \\
\text { ethical review and } \\
\text { greater formal } \\
\text { consideration of } \\
\text { research projects. }\end{array}$ & $\begin{array}{l}\text { Explore igsues } \\
\text { experienced by } \\
\text { researchers doing } \\
\text { qualitative health } \\
\text { research on a } \\
\text { gensitive topic. }\end{array}$ \\
\hline
\end{tabular}

\begin{tabular}{|c|c|c|c|c|c|c|c|c|}
\hline Title & $\begin{array}{l}\text { 'Ethical Dilemmas } \\
\text { and Practical } \\
\text { Problems for the } \\
\text { Practitioner } \\
\text { Researcher' }\end{array}$ & $\begin{array}{l}\text { 'Ethical } \\
\text { Components of } \\
\text { Researcher- } \\
\text { Researched } \\
\text { Relationghips in } \\
\text { Qualitative } \\
\text { Interviewing' }\end{array}$ & $\begin{array}{l}\text { 'This Morming I'm } \\
\text { a Researcher, This } \\
\text { Afternoon I'm an } \\
\text { Outreach Worker. } \\
\text { Ethical Dilemmas } \\
\text { in Practitioner } \\
\text { Research' }\end{array}$ & $\begin{array}{l}\text { 'Blurring } \\
\text { Boundaries in } \\
\text { Qualitative Health } \\
\text { Research on } \\
\text { Sensitive Topics' }\end{array}$ & $\begin{array}{l}\text { 'Methodological } \\
\text { Issues Associated } \\
\text { with Studying an } \\
\text { Illegal Act' }\end{array}$ & $\begin{array}{l}\text { 'Ethics, Reflectivity } \\
\text { and Ethically } \\
\text { Important Moments' }\end{array}$ & $\begin{array}{l}\text { 'Accident and } \\
\text { Emergency } \\
\text { Nurses as } \\
\text { Researchers: } \\
\text { Exploring Some } \\
\text { of the Ethical } \\
\text { Issues when } \\
\text { Researching } \\
\text { Sengitive Topics' }\end{array}$ & $\begin{array}{l}\text { 'Undertaking } \\
\text { Sensitive } \\
\text { Research: Issues } \\
\text { and Strategies for } \\
\text { Meeting the } \\
\text { Safety Needs of } \\
\text { All Participants' }\end{array}$ \\
\hline Authors & Fraser, D. M. & Hewitt, J. & Coy, M. & $\begin{array}{l}\text { Dickson-Swift, V., } \\
\text { James, E. L.., } \\
\text { Kippen, S., \& } \\
\text { Liamputtong, p. }\end{array}$ & Volker, D. L. & $\begin{array}{l}\text { Guillemin, M., \& } \\
\text { Gillam, L. }\end{array}$ & $\begin{array}{l}\text { Murphy, F, \& } \\
\text { Nightingale, A. }\end{array}$ & $\begin{array}{l}\text { McCoaker, H., } \\
\text { Bannard, A., \& } \\
\text { Gerber, R. }\end{array}$ \\
\hline Publication year & 2007 & 2007 & 2006 & 2006 & 2004 & 2004 & 2002 & 2001 \\
\hline Journal & $\begin{array}{l}\text { Educational Action } \\
\text { Research }\end{array}$ & $\begin{array}{l}\text { Qualitative Heaith } \\
\text { Research }\end{array}$ & $\begin{array}{l}\text { Intermational } \\
\text { Journal of Social } \\
\text { Research } \\
\text { Methodology }\end{array}$ & $\begin{array}{l}\text { Qualitative Heaith } \\
\text { Research }\end{array}$ & $\begin{array}{l}\text { Adivances in } \\
\text { Nursing }\end{array}$ & $\begin{array}{l}\text { Research in } \\
\text { Qualitative Inquiry }\end{array}$ & $\begin{array}{l}\text { Accident and } \\
\text { Emergency } \\
\text { Nursing }\end{array}$ & $\begin{array}{l}\text { Qualitative Social } \\
\text { Research }\end{array}$ \\
\hline Aim/topic & $\begin{array}{l}\text { Explore the ethical } \\
\text { dilemmas involved } \\
\text { in action research } \\
\text { study in the } \\
\text { author's school. }\end{array}$ & $\begin{array}{l}\text { Examine the } \\
\text { relationship } \\
\text { between the } \\
\text { researcher and the } \\
\text { researched and the } \\
\text { ethical dilemmas } \\
\text { that arise from the } \\
\text { intrugive nature of } \\
\text { the qualitative } \\
\text { interview. }\end{array}$ & $\begin{array}{l}\text { Analyse ethical } \\
\text { dilemmas involved } \\
\text { in conducting } \\
\text { participatory } \\
\text { action research } \\
\text { among women } \\
\text { gelling sex. }\end{array}$ & $\begin{array}{l}\text { Investigate the } \\
\text { potential boundary } \\
\text { issues experienced } \\
\text { by qualitative } \\
\text { health researchers. }\end{array}$ & $\begin{array}{l}\text { Explore } \\
\text { methodological } \\
\text { issues and } \\
\text { approaches to } \\
\text { studying an } \\
\text { ethically and } \\
\text { legally gensitive } \\
\text { igsue. }\end{array}$ & $\begin{array}{l}\text { Examine the } \\
\text { relationship between } \\
\text { reflexivity and } \\
\text { research ethics }\end{array}$ & $\begin{array}{l}\text { Explore ethical } \\
\text { issues when } \\
\text { nurses as } \\
\text { researchers } \\
\text { conduct research } \\
\text { on sensitive topics } \\
\text { in the ambulance } \\
\text { and emergency } \\
\text { getting. }\end{array}$ & $\begin{array}{l}\text { Explore how all } \\
\text { participants are } \\
\text { affected by } \\
\text { gensitive } \\
\text { qualitative } \\
\text { research. }\end{array}$ \\
\hline
\end{tabular}




\section{Analysis}

Thematic analysis is widely used in qualitative research to uncover patterns or themes in data (Braun \& Clarke, 2006). This analytical approach has also been applied to review articles (Pool et al., 2019; Yousif \& Passo, 2016) and is recommended as an important stage in review protocols (Stenberg et al., 2018). One derivative of thematic analysis is thematic synthesis (Thomas \& Harden, 2008), which is often applied to literature reviews to identify and further develop descriptive themes into analytical themes. While thematic synthesis provides the analytical structure for this scoping review, it was influenced by Braun and Clarke's (2006) step-by-step method, which involves going back and forth between codes and themes to ensure consistency, not establishing themes solely based on a few vivid examples.

After all 24 selected studies were reviewed, initial codes were generated for the analysis. In the next step, the codes were reviewed, and themes were identified. In the third stage, descriptive themes were developed into overarching analytical themes: 'researcher vulnerability', 'researcher competency', 'researcher role', and 'participant vulnerability'. Some codes could be placed in several categories; for example, the topics 'boundary issues in qualitative research' and 'blurring of roles' both offer challenges and make the researcher vulnerable to pressure, stress, or incorrect expectations on the part of participants. This problem of overlapping categories could be prevented if the research preparations (a part of researcher competency) were to include information that clearly defines what the research is about (and is not about) and what the participant may expect. Also, in face-to-face meetings and interviews, the researcher could employ a set of skills during analysis and communication with the participant, which might adjust the participant's understanding of who and what the researcher is and is not and clarify blurred roles or uncertainties about the research agenda. 


\section{Findings}

Figure 2

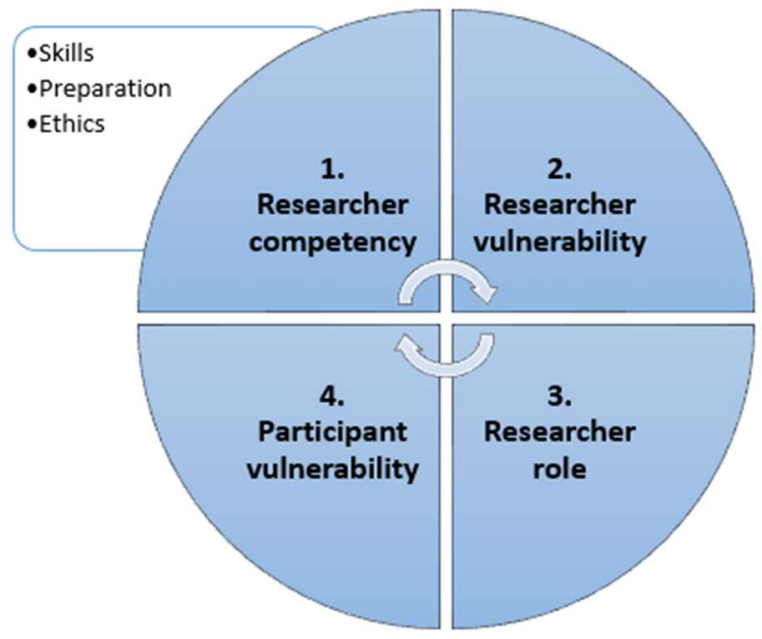

\section{Theme 1: Researcher Competency}

The theme 'competency' includes several subthemes. One dimension within competency involves the skills needed to actually carry out research. The scoping review found skills at three levels: 'communication skills', 'empathic skills', and 'emotional management'. Researchers need communication skills to deal with participants' feelings and engage in small talk to relax the participant (Ashton, 2014; Elmir et al., 2011; Murphy \& Nightingale, 2002), while proficiency with interview techniques is essential in exploring their experiences (Thompson \& Russo, 2012). Unforeseen situations can arise when engaging with research participants, and being able to de-escalate potentially threatening situations has been recognised as a skill that researchers should possess (Bashir, 2018). The researcher must also be able to analyse and adapt to participants' nonverbal communications, both to show empathy and to continue the interview (Ashton, 2014; Elmir et al., 2011; Murphy \& Nightingale, 2002). There seems to be a consensus regarding the ability to demonstrate empathy in interview situations and provide the necessary support to participants, both in the interviews and after the research, if needed. When exposed to the participants' stories and feelings, the researcher might feel overwhelmed. Some findings have revealed the need to be able to manage one's own feelings when conducting this kind of research (Ashton, 2014), while also showing 
that disclosing details about oneself may help the participants feel less intimidated. Revealing personal information about oneself was also highlighted as a potential risk that could render the researcher more vulnerable in the process (Elmir et al., 2011). In addition to managing one's emotions during research, some evidence was found to support the value of self-care actions between or after research activities (Coles et al., 2014).

Another dimension of competency is researcher preparation. After once again reviewing the codes and themes, two sub-subthemes emerged within 'preparation competency': 'interview preparation' and 'support preparation'. Most of what has been organised into this subtheme relates to how the researcher can design and execute the interview in a manner that is well thought through and safe for the researcher. This involves evaluating whether the research should be conducted by one researcher alone or with support from other researchers, how the researcher's background could affect the participants (Gabriel et al., 2017), and how to establish protocols for dealing with boundary issues (Dickson-Swift et al., 2006). Careful preparation for the interview should also consider the participant as a vulnerable part of the research, who should be taken into account in the research planning (Elmir et al., 2011; McCosker et al., 2001; Murphy \& Nightingale, 2002). Time management and the intensity of conducting the actual interviews were also recognised as components of research preparation that are critical to ensuring the researcher's well-being (Coles et al., 2014). The other subtheme of preparation relates to the potential need for the support of both participants and researchers during the research and after it was conducted. Supervision, debriefing, peer support, and group sessions were suggested as means that might strengthen the researcher during the research process, making it easier to conduct challenging interviews and deal with the participants' emotions and trauma (Bashir, 2018; Coles et al., 2014; Flanagan, 2012; Gabriel et al., 2017; Thompson \& Russo, 2012).

Some findings could easily be placed in more than one category or theme, such as the legal actions that both participants and researchers might experience when conducting research on illegal acts. This was exemplified in an article by Volker (2004) that concerned nurses who had received requests for assisted dying from terminally ill patients. Such a situation puts the participant at risk of having his/her identity revealed should the research team be subpoenaed by the federal government (the US, in this 
case). Researchers themselves may be subject to legal prosecution if they do not respond to the subpoena. To manoeuvre around these legal issues, Volker (2004) presented a study design in which research packages mailed to a large sample of nurses included anonymous recipient response packages.

Regarding ethical competency, Pain (2011) found it important to have a well-thoughtthrough approach to practitioner research methodology and ensure that this approach resonates with the ethics of social work. Pain (2011) also stressed that the researcher's attitude toward power dynamics is a key ethical issue. Several studies found a need for ethical reflection throughout the entire research process (Coy, 2006; Mitchell et al., 2010; Pain, 2011; Thompson \& Russo, 2012) and moving beyond simple ethical codes of conduct (Fraser, 2007; Hewitt, 2007; Lunt \& Fouché, 2010). Guillemin and Gillam (2004) found that applications to committees seeking ethical approval were written in a language that gave the impression that the researchers were competent and concerned with ethical dilemmas. Guillemin and Gillam (2004) called this 'procedural ethics', which they distinguished from microethics in researcher practice. In practice, microethics can involve an unpredictable situation in which the researcher must make on-the-spot decisions.

Practitioner research may involve small-scale studies in the form of evaluations of interventions in which the practitioner researcher was involved, thus increasing the potential for conflicts of interest (Lunt \& Fouché, 2010). While several studies acknowledged the dual role of the practitioner researcher as potentially challenging (Lunt \& Fouché, 2010; Mitchell et al., 2010), the role was also found to mitigate the study's negative impacts on participants because a relationship of trust may already exist (Coy, 2006).

Two studies also identified a lack of ethical consideration in practitioner research (Bryan \& Burstow, 2018; Mitchell et al., 2010). Confidentiality, anonymity, informed consent, and the right to withdraw consent were not considered by researchers in the execution of their research. The findings from Mitchell et al.'s (2010) study revealed the attitude that research in schools cannot harm the pupils and that consent to participate in studies is effectively granted when parents sign their children up at the start of school. Bryan and Burstow (2018) also found that anonymity is explicitly undesirable because it limits the 
possibility of following up on the answers provided by pupils on questionnaires about bullying and well-being at school. On the positive side, Mitchell et al. (2010) found nine studies that followed the basic ethical principles of research, including in terms of how they gained access to participants, how consent was obtained, and how the research design aimed to ensure anonymity and confidentiality throughout the process.

Overall, the level of necessary competency identified in this scoping review demands knowledge and oversight of both planning and execution, as well as the ethical risks and tripwires that can be encountered. If the practitioner researcher has a low level of competence in professional research, including a poor understanding of the recruitment process, interviewing, and the analysis and reporting of data, then the researcher, the results, and the participants may all be negatively impacted. Researcher vulnerability is explored further in the following section.

\section{Theme 2: Researcher Vulnerability}

Researcher vulnerability is naturally difficult to measure or divide into levels of severity. However, the analysed articles indicated various degrees of emotional unpleasantness. Stress, upsetting information, and traumatised participants (Ashton, 2014; Bashir, 2018; Coles et al., 2014; Dickson-Swift et al., 2006, 2008; Hassan, 2016; McCosker et al., 2001; Murphy \& Nightingale, 2002) might be less stressful topics for one researcher, while another researcher might experience burnout and vicarious traumatisation (Coles et al., 2014; Dickson-Swift et al., 2006, 2008; Elmir et al., 2011; Gabriel et al., 2017; McCosker et al., 2001). Stress can be defined as 'an emotional experience accompanied by predictable biochemical, physiological, and behavioral changes' (Baum, 1990). At the far end of the scale is burnout syndrome, which is characterised by significant physical and/or psychological exhaustion, a high level of depersonalization (toward participants and/or clients), and a lack of achievement or professional accomplishment (Maslach \& Jackson, 1981). This highlights not only the substantial variation in emotional unpleasantness experienced by qualitative researchers involved in research on sensitive topics but also the fact that lesser degrees of unpleasantness can evolve over time into more serious and chronic issues. Some articles also thematised the fact that the social researcher role itself was perceived differently by and was sometimes unclear to the participants in the studies (Dickson-Swift et al., 2006; Elmir et al., 2011; Hassan, 2016); 
for example, participants would question whether the researcher was a therapist or counsellor or was a 'spy'. This confusion has the potential to create unpleasantness and stress for both participants and researchers because research on sensitive topics demands a certain level of participant comfort to reveal sensitive matters (Elmir et al., 2011). The scholarly literature also recognised the interview location as a source of stress or discomfort when conducting research on sensitive topics (Bashir, 2018; Coles et al., 2014). Feeling connected to the participants was also found to generate negative emotional responses in the researchers (Bashir, 2018; Gabriel et al., 2017).

\section{Theme 3: Researcher Role}

The third theme identified through the analysis was 'the role of the researcher' in practitioner research. Several studies identified ethical dilemmas related to the dual roles of the practitioner who steps out of his/her role as a practitioner to engage in research in the same workplace, thus creating the possibility for more dilemmas than might be experienced by the professional researcher (Fraser, 2007; Mitchell et al., 2010). These blurred roles were especially challenging in qualitative research because this concerned confidentiality and anonymity (Lunt \& Fouché, 2010) when, for example, evaluation research was conducted within the practitioner researcher's own organisation. In a study of public health nurses, Clancy (2011), herself a nurse, became aware of her own physical reaction to being an intrusion into clinical practice that disturbed the nurse and patient she was observing. Upon reflection, Clancy found that her own reactions might act as a reminder of the vulnerability of everyone involved in the research because she was prompted to question the justification of her presence itself. Mitchell et al. (2010) also noted that some researchers in practitioner research found the dual role to be a preferred standpoint for research. Coy (2006) discovered that the role of practitioner researcher provided an opening and access to hard-to-reach targets. In contrast, several studies identified in a review laid out the dilemmas of the dual role, though these dilemmas were not stated specifically or described thoroughly, nor was it made clear how they were addressed (Mitchell et al., 2010). While professional ethical codes of conduct were found to serve as general guidelines, they were also largely inapplicable to the researcher (Lunt \& Fouché, 2010). While there was some discussion of the blurred and overlapping roles of the practitioner researcher, some evidence suggested that participants might experience the research process as therapeutic. Research being 
conducted by a familiar professional might also help reduce the number of people to whom the participant reveals sensitive information (Vaswani, 2018). This might be a way of taking care of and protecting potentially vulnerable participants.

\section{Theme 4: Participant Vulnerability}

The fourth theme identified in the analysis was 'participant vulnerability' in practitioner research. In their study of school leaders and their thoughts regarding ethical awareness in school research, Bryan and Burstow (2018) found that anonymity was undesirable because part of the research required them to go back and talk to the pupils about their answers regarding bullying and well-being in school. Clancy (2011) revealed similar findings in which practitioner researchers did not ensure participant anonymity and confidentiality due to their dual roles. A study by Pain (2011) found that the power dynamics between client and social worker or therapist touched upon ethical dilemmas in practitioner research because these power dynamics cannot be completely overcome when recruiting participants. This may create a problematic position for clients when deciding whether to give informed consent to participate. Participants' fear of the negative consequences of denying or withdrawing consent in this context was recognized by Lunt and Fouché (2010). Similarly, others have found it necessary to explicitly inform participants that consent can be withdrawn (Thompson \& Russo, 2012). Researching children (Vaswani, 2018) and children's sexuality (Flanagan, 2012) demands a sensitive approach. In an attempt to reduce the power imbalance between herself and the children participating in her research, Vaswani (2018) used photoelicitation and shared with the children how and what was to be discussed. Also, in smallsample-size case studies, it may be challenging to report the results in a rich manner that does not reveal the identity of the participants (Tietze, 2012).

\section{Recommendations}

Eight articles provided recommendations to support the researcher and/or participants and safeguard those involved from unpleasant experiences when dealing with sensitive research topics. The recommendations also suggested the value of striving to maintain ethical standards and conduct good ethical practices in practitioner research. The suggestions were either stated specifically as suggestions in the articles or were 
extracted as part of the thematic analysis. The suggestions can be divided into two main categories, or subthemes — supervision and increased researcher competence — which are interlinked to some extent. Supervision in practitioner research was a common theme throughout the suggestions in the studies (Bashir, 2018; Coles et al., 2014; Flanagan, 2012; Gabriel et al., 2017; Thompson \& Russo, 2012). Partnering with a professional research community or individual partner throughout the entire research process was also advised (Mitchell et al., 2010; Pain, 2011) to ensure ethical oversight and allow for greater research flexibility, especially when dealing with ethical dilemmas (Coy, 2006; Lunt \& Fouché, 2010). Bryan and Burstow (2018) identified the need for a better understanding of the dimensions of research ethics in research conducted through schools. Similar findings by Fraser (2007) noted that ethical considerations should be measured before research is conducted in the field. As pointed out above, professional ethical codes of conduct may also serve as general ethical guidelines for practitioner research (Lunt \& Fouché, 2010), but there is also a need to establish both guidelines and procedures to deal with the ethical dilemmas that occur during the research process.

\section{Discussion and Implications for Practice in the Nordic Context}

This article is written from a Norwegian perspective, and the Nordic context was addressed briefly in the introduction. The Nordic welfare system aims to provide the entire population with similar services, and practitioners in this field (social workers, nurses, and others) are of particular interest regarding practitioner research. However, the findings of this scoping review may be transferable to other countries with similar legislation. In Norway, respect for the human dignity and vulnerability of those involved in research is regulated both ethically and legally through the National Committee for Research Ethics in the Social Sciences and the Humanities (NESH) and the Norwegian Centre for Research Data. The national guidelines for research ethics state that when dealing with vulnerable groups, researchers must place particular emphasis on the requirements regarding information and consent $(\mathrm{NESH}, 2016$, p. 25). This becomes increasingly important when conducting practitioner research in which clients and other service users serve as informants. 
Social work is conventionally described as 'one of few professions where one will execute both control and compassionate solidarity, as in child protective services and the welfare services' (Levin, 2004, p. 11). This uneven power relationship may place unjust pressure on potential research participants, as noted by Lunt and Fouché (2010), thus forcing quick and hasty decisions about whether to participate. This ethical dilemma is also recognised in research outside of this paper's scope, such as in primary care (Wilson et al., 2008). The role and expectations of the practitioner researcher may be at the core of the issues highlighted in this scoping review because they connect with many of the aspects highlighted in the findings. Additionally, social workers, teachers, and nurses share the goal of ensuring the well-being, growth, and safety of their clients or pupils (Sivenbring \& Malmros, 2020). This goal might not necessarily be in accordance with the goal of the practitioner research project, thus creating inner conflicting expectations in which the practitioner researcher struggles with how to both carry out the research and take care of the participant and him- or herself at the same time. This expands the inner conflict presented by Hochschild (2003) and Kahn et al. (1964), among others. Kahn et al. (1964) state that a core element in all types of roles and personal conflicts in organisational life was experiencing two or more sets of pressures such that compliance with one would make compliance with the other challenging. The current subject, practitioner research, adds another component, or role, to this already complex interplay of personal and professional factors. For the professionals mentioned in this study, those who support and care for others (Sivenbring \& Malmros, 2020), this might manifest as a strong ethical dilemma and create uncertainty and stress.

As the analysis showed, it is challenging to include ethics in every part of a research project. The formal ethical considerations reportedly followed by some studies are a starting point, but they must be followed by ethical practitioner researchers at every step of the research process. There is also evidence that the ethical guidelines within which social workers, among others, conduct their professions are not enough to ensure sufficient ethical consideration when undertaking research. The analysis found indications of an overall lack of research competency in practitioner research.

Several articles highlighted recommendations of support for practitioner researcher and participants when dealing with sensitive research topics. These findings can point the practitioner researcher in the direction of partnering with a mentor or supervisor (perhaps 
a professional research community, such as a university) for supervision and recommendations in all stages of the research. Because several authors represented low-level research competency as a challenge in the practitioner research field and found that the poor planning and execution of research may lead to unpleasant experiences for both parties, the recommendation of strong partnerships and academic supervision is this review's main take-home message. By engaging closely with a professional research institution, practitioner researchers might strengthen their competency and secure both themselves and their participants in the research process. Supervision from senior researchers might also help practitioner researchers engaged in more novel research better grasp the complexity of combining these two roles. If the practitioner researcher and the findings and insights that surface from their research are to be taken as seriously as other research strategies, efforts should be made to heighten the researcher's competency and skills. If not, the valuable cooperation between researcher and practice institutions may not be utilised, and hard-to-reach targets may be left out of traditional research projects' grasp. One solution might be to strengthen and increase the amount of research methodology in bachelor's degree curricula.

However, when conducting this scoping review, bachelor's degree curricula were not assessed or explored, and therefore, the author of this manuscript is unsure how much attention these topics currently receive during bachelor's studies in Norway or other Nordic countries. While strengthening research methodology is one available option, it must be weighed against all other subjects and topics in these educational programmes. Concerns have already been raised about theoretical academic disciplines consuming too much time in Norwegian nursing education (Caspersen, 2017) and Danish teacher education (Rambøll Management Consulting, 2012). A debate about this is welcome, and the author of this scoping review hopes the findings presented will bring insight and discussion to both practitioners and researchers. Research over the next decade will hopefully venture down the avenues mapped out by this scoping review and potentially influence educational institutions, the practice field, and its professionals. To aid both professionals and participants, the evolution of practitioner research should include the development of a comprehensive and understandable merger between professional ethics and research ethics, along with strong partnerships with research communities. 


\section{Limitations}

The findings are limited because the search methodologies in the included reviews were not thoroughly presented. However, all included articles were peer reviewed and were found through recognised databases and sources. The larger body of included articles contains original empirical data. As the author of the scoping review, I strived to avoid adding or removing any meaning to or from the original content of the identified articles. To address my subjectivity, identified articles were analysed twice, with similar results.

\section{Conclusion}

Through an investigation of 24 peer-reviewed studies, this scoping review found evidence of some very challenging issues that have arisen within practitioner research on sensitive topics, such as exposure to participants' trauma and the blurred roles between practitioner and researcher. These dilemmas surface due to the complexity of roles and tasks within practitioner research. Specifically, the role-related expectations regarding behaviour, appearance, and the display of emotions in accordance with both the practitioner and researcher roles are of relevance to understanding this challenging research. This should be followed up on in future studies of practitioner research, with a specific focus on the connection and complexity of both roles and the way in which these are juggled within research settings.

Also, like qualitative research in general, practitioner research on sensitive topics demands certain skills in planning, executing, and taking care of both the participants and oneself as a researcher. One must develop the capacity to reflect upon ethical dilemmas mid-research and resolve other issues with fellow researchers afterward. Peer support and supervision from professional research communities, such as a university, might help both novice and more experienced practitioners develop into more resilient and ethically aware researchers. Learning how former practitioner researchers have navigated their difficult experiences may provide guidance and a sense of security to those researching within the demanding contexts of social work, nursing, and related professions. Doing so has the potential to create an increased sense of security for both practitioners and participants, thus building stronger ties among research communities, welfare services, and their service users. 


\section{References}

Ashton, S. (2014). Researcher or nurse? Difficulties of undertaking semistructured interviews on sensitive topics. Nurse Researcher, 22(1), 27-31. https://doi.org/10.7748/nr.22.1.27.e1255

Austin, Z., \& Sutton, J. (2014). Qualitative research: Getting started. The Canadian Journal of Hospital Pharmacy, 67(6), 436-440. https://doi.org/10.4212/cjhp.v67i6.1406

Bashir, N. (2018). Doing research in peoples' homes: Fieldwork, ethics and safety - on the practical challenges of researching and representing life on the margins. Qualitative Research, 18(6), 638-653. https://doi.org/10.1177/1468794117731808

Baum, A. (1990). Stress, intrusive imagery, and chronic distress. Health Psychology, 6, 653-675. https://doi.org/10.1037/0278-6133.9.6.653

Bonevski, B., Randell, M., Paul, C., Chapman, K., Twyman, L., Bryant, J., \& Hughes, C. (2014). Reaching the hard-to-reach: A systematic review of strategies for improving health and medical research with socially disadvantaged groups. BMC Medical Research Methodology, 14, 42. doi:10.1186/1471-2288-14-42. https://doi.org/10.1186/1471-2288-14-42

Braun, V., \& Clarke, V. (2006). Using thematic analysis in psychology. Qualitative Research in Psychology, 3, 77-101. https://doi.org/10.1191/1478088706qp063oa

Brown, J. (1996). Police research: Some critical issues. In F. Leishman, B. Loveday, \& S. P. Savage (Eds.), Core issues in policing. Longman.

Bryan, H., \& Burstow, B. (2018). Understanding ethics in school-based research. Professional Development in Education, 44(1), 107-119. https://doi.org/10.1080/19415257.2017.1361464

Caspersen, J. (2017, November 28). Kan akademiseringen av sykepleiefaget ha gått på bekostning av yrkesrelevansen? Fagbladet. Retrieved from https://fagbladet.no/meninger/kan-akademiseringen-av-sykepleiefaget-hagatt-pa-bekostning-av-yrkesrelevansen-6.115.498574.cb270186ce

Clancy, A. (2011). An embodied response: Ethics and the nurse researcher. Nursil Ethics, 18(1), 112-121. https://doi.org/10.1177/0969733010385531

Coles, J., Astbury, J., Dartnall, E., \& Limjerwala, S. (2014). A qualitative exploration of researcher trauma and researchers' responses to investigating sexual violence. Violence Against Women, 20(1), 95-117. doi:10.1177/1077801213520578 https://doi.org/10.1177/1077801213520578

Coy, M. (2006). This morning I'm a researcher, this afternoon I'm an outreach worker: Ethical dilemmas in practitioner research. International Journal of Social Research Methodology, 9(5), 419-431. https://doi.org/10.1080/13645570601076785

Davis, H. (2000). The management of self: Practical and emotional implications of ethnographic work in a public hospital setting. In K. R. Gilbert (Ed.), The 
Emotional Nature of Qualitative Research (pp. 37-59). CRC Press. https://doi.org/10.1201/9781420039283.ch3

Dickson-Swift, V., James, E. L., Kippen, S., \& Liamputtong, P. (2006). Blurring boundaries in qualitative health research on sensitive topics. Qualitative Health Research, 16(6), 853-871. https://doi.org/10.1177/1049732306287526

Dickson-Swift, V., James, E. L., Kippen, S., \& Liamputtong, P. (2008). Risk to researchers in qualitative research on sensitive topics: Issues and strategies. Qualitative Health Research, 18(1), 133-144. https://doi.org/10.1177/1049732307309007

Drake, P., \& Heath, L. (2010). Practitioner research at doctoral level: Developing coherent research methodologies (1st ed.). Routledge. https://doi.org/10.4324/9780203841006

Ellis, N., \& Loughland, T. (2016). The challenges of practitioner research: A comparative study of Singapore and NSW. Australian Journal of Teacher Education, 41(2), 112-136. https://doi.org/10.14221/ajte.2016v41n2.8

Elmir, R., Schmied, V., Jackson, D., \& Wilkes, L. (2011). Interviewing people about potentially sensitive topics. Nurse Researcher, 19(1), 12-16. https://doi.org/10.7748/nr2011.10.19.1.12.c8766

Flanagan, P. (2012). Ethical review and reflexivity in research of children's sexuality. Sex Education, 12(5), 535-544. https://doi.org/10.1080/14681811.2011.627731

Flanagan, S. M., \& Hancock, B. (2010). Reaching the hard to reach - lessons learned from the VCS (voluntary and community sector): A qualitative study. BMC Health Services Research, 10, 92. https://doi.org/10.1186/1472-6963-10-92

Fraser, D. M. (2007). Ethical dilemmas and practical problems for the practitioner researcher. Educational Action Research, 5(1), 161-171. https://doi.org/10.1080/09650799700200014

Gabriel, L., James, H., Cronin-Davids, J., Tizro, Z., Beetham, T., Hullock, A., \& Raynar, A. (2017). Reflexive research with mothers and children. Counselling and Psychotherapy Research, 17(2), 157-165. https://doi.org/10.1002/capr.12117

Guillemin, M., \& Gillam, L. (2004). Ethics, reflectivity and ethically important moments. Research in Qualitative Inquiry, 10(2), 261-280. https://doi.org/10.1177/1077800403262360

Harvey, D., Plummer, D., Pighills, A., \& Pain, T. (2013). Practitioner research capacity: A survey of social workers in Northern Queensland. Australian Social Work, 66(4), 540-554. https://doi.org/10.1080/0312407X.2012.754916

Hassan, N. (2016). Surviving research on sensitive topics with young offenders. Scottish Journal of Residential Child Care, 15(1), 102-114.

Hewitt, J. (2007). Ethical components of researcher-researched relationships in qualitative interviewing. Qualitative Health Research, 17(8), 1149-1159. https://doi.org/10.1177/1049732307308305 
Hochschild, A. R. (2003). The managed heart: Commercialization of human feeling (20th anniversary ed.). University of California Press. https://doi.org/10.1525/9780520930414

Hoydal, M. (2018, June 7). Social policy and welfare. Nordic Co-operation. https://www.norden.org/en/information/social-policy-and-welfare.

Kahn, R.L., Wolfe, D.M., Quinn, R.P., Snoek, J. D., \& Rosenthal, R.A. (1964). Organizational stress: Studies in role conflict and ambiguity. New York: Wiley.

Kirkevold, M., \& Bergland, Å. (2007). The quality of qualitative data: Issues to consider when interviewing participants who have difficulties providing detailed accounts of their experiences. International Journal of Qualitative Studies on Health and Well-Being, 2(2), 68-75. https://doi.org/10.1080/17482620701259273

Levin, I. (2004). Hva er sosialt arbeid. Universitetsforlaget.

Lunt, N., \& Fouché, C. (2010). Practitioner research, ethics and research governance. Ethics and Social Welfare, 4(3), 219-235. https://doi.org/10.1080/17496535.2010.516117

Maslach, C., \& Jackson, S. E. (1981). The measurement of experienced burnout. Journal of Organizational Behaviour, 2(2), 99-113. https://doi.org/10.1002/job.4030020205

McCosker, H., Barnard, A., \& Gerber, R. (2001). Undertaking sensitive research: Issues and strategies for meeting the safety needs of all participants. Forum: Qualitative Social Research, 2(1), 1-15

Meghan, M. M. (2019). Action research and systematic, intentional change in teaching practice. Review of Research in Education, 43, 163-196. https://doi.org/10.3102/0091732X18821132

Mitchell, F., Lunt, N., \& Shaw, I. (2010). Practitioner research in social work: A knowledge review. Evidence \& Policy, 6(1), 7-31. https://doi.org/10.1332/174426410X482971

Moher, D., Liberati, A., Tetzlaff, J., \& Altman, D. G. (2009). Preferred reporting items for systematic reviews and meta-analyses: The PRISMA statement. PLoS Medicine, 6(7), 6. https://doi.org/10.1371/journal.pmed.1000097

Munn, Z., Peters, M. D. J., Stern, C., Tufanaru, C., McArthur, A., \& Aromataris, E. (2018). Systematic review or scoping review? Guidance for authors when choosing between a systematic or scoping review approach. BMC Medical Research Methodology, 18(143), 1-7. https://doi.org/10.1186/s12874-018-0611-x

Murphy, F., \& Nightingale, A. (2002). Accident and emergency nurses as researchers: Exploring some of the ethical issues when researching sensitive topics. Accident and Emergency Nursing, 10, 72-77. https://doi.org/10.1054/aaen.2001.0342

National Committee for Research Ethics in the Social Sciences and the Humanities. (2016). Guidelines for research ethics in the social sciences, humanities, law and theology. Oslo: NESH. 
Normann, T. M., Rønning, E., \& Nørgaard, E. (2014). Challenges to the Nordic welfare state- comparable indicators (2nd ed.). Nordic Social-Statistical Committee (NOSOSCO).

Pain, H. (2011). Practice research: What it is and its place in the social work profession. European Journal of Social Work, 14(4), 545-562. https://doi.org/10.1080/13691457.2010.490062

Parsons, T. (1969). Research with human subjects and the 'professional complex'. Daedalus, 98(2), 325-360.

Patton, M. Q. (1999). Enhancing the quality and credibility of qualitative analysis. Health Services Research, 34(5), 1189-1208.

Pham, M. T., Rajić, A., Greig, J. D., Sargeant, J. M., Papadopoulos, A., \& McEwen, S. A. (2014). A scoping review of scoping reviews: Advancing the approach and enhancing the consistency. Research Synthesis Methods, 5(4), 371-385. https://doi.org/10.1002/jrsm.1123

Pool, J., Akhlaghpour, S., Fatehi, F., \& Burton-Jones, A. (2019, July). Causes and impacts of Personal Health Information (PHI) breaches: A scoping review and thematic analysis [Conference presentation]. 23rd Pacific Asia Conference on Information Systems, Xi'an, China.

Rambøll Management Consulting. (2012). Evaluering af Pædagoguddannelsen (p. 71). Ministeriet for Forskning, Innovation og Videregående Uddannelser.

Riese, J. (2019). What is 'access' in the context of qualitative research? Qualitative Research, 19(6), 669-684. https://doi.org/10.1177/1468794118787713

Seidman, I. (2006). Interviewing as qualitative research: A guide for researchers in education and the social sciences (3rd ed.). Teachers College Press.

Shaw, I., \& Lunt, N. (2018). Forms of practitioner research. British Journal of Social Work, 48(1), 141-157. https://doi.org/10.1093/bjsw/bcx024

Sivenbring, J. \& Malmros, R. A. (2020). Mixing logics: Multiagency approaches for countering violent extremism. Segerstedtinstitutet.

Stenberg, M., Mangrio, E., Bengtsson, M., \& Carlson, E. (2018). Formative peer assessment in healthcare education programmes: Protocol for a scoping review. BMJ Open, 8(11). https://doi.org/10.1136/bmjopen-2018-025055

Sydor, A. (2013). Conducting research into hidden or hard-to-reach populations. Nurse Researcher, 20(3), 33-37. https://doi.org/10.7748/nr2013.01.20.3.33.c9495

Thomas, J., \& Harden, A. (2008). Methods for the thematic synthesis of qualitative research in systematic reviews. BMC Medical Research Methodology, 8(1), 45. https://doi.org/10.1186/1471-2288-8-45

Thompson, A. R., \& Russo, K. (2012). Ethical dilemmas for clinical psychologists in conducting qualitative research. Qualitative Research in Psychology, 9(1), 32-46. https://doi.org/10.1080/14780887.2012.630636

Tietze, S. (2012). Researching your own organization. In G. Symon \& C. Cassell (Eds.), Qualitative organizational research: Core methods and current challenges (pp. 53-71). SAGE Publications. https://doi.org/10.4135/9781526435620.n4 
Vaswani, N. (2018). Learning from failure: Are practitioner researchers the answer when conducting research on sensitive topics with vulnerable children and young people? International Journal of Social Research Methodology, 21(4), 499-512.

https://doi.org/10.1080/13645579.2018.1434866

Volker, D. L. (2004). Methodological issues associated with studying an illegal act. Advances in Nursing, 27(2), 117-128. https://doi.org/10.1097/00012272-200404000-00005

Wilson, S., Draper, H., \& Ives, J. (2008). Ethical issues regarding recruitment to research studies within the primary care consultation. Family Practice, 25(6), 456-461. https://doi.org/10.1093/fampra/cmn076

Yousif, M., \& Passo, K. (2016). IT agility research review: Thematic analysis and categorization of literature (Proceedings No. 205). PACIS.

https://aisel.aisnet.org/pacis2016/205/ 